\title{
FIQH AL-BI'AH RAMAH LINGKUNGAN: \\ KONSEP THAHARAH DAN NADHAFAH DALAM MEMBANGUN BUDAYA BERSIH
}

\author{
Oleh: \\ Jamaluddin \\ jamaluddin_bukhori@gmail.com \\ Institut Agama Islam Tribakti (IAIT) Kediri
}

\begin{abstract}
Abstrak
Realitas sosial saat ini telah membuktikan adanya kerusakan lingkungan hidup yang sangat masif. Penanganannya secara teknik-intelektual sudah banyak diupayakan, tetapi secara moral-spiritual belum mendapatkan perhatian yang cukup serius. Oleh karena itu pemahaman masalah lingkungan hidup dan penanganannya harus diletakkan pada suatu fondasi moral yang kuat dengan cara menghimpun dan merangkai sejumlah prinsip. Prinsip nilai, prinsip norma, (baik sosial maupun norma susila), dan kepastian hukum yang bersumber dari ajaran agama dan konstitusional. Dalam rangka mengatasi krisis lingkungan hidup yang sekarang sedang melanda dunia tidak hanya persoalan teknis, ekonomi, politik, hukum dan sosial budaya semata, melainkan diperlukaan upaya penyelesaian dari berbagai perspektif, termasuk salah satunya adalah perspektif fiqh. Karena fiqh pada dasarnya merupakan "jembatan penghubung" antara etika (perilaku manusia) dan normanorma hukum untuk kesalamatan alam semesta (ekosistem) di dunia ini.
\end{abstract}

Kata Kunci: Al-Bi'ah, Konsep Thaharah - Nadhafah, Budaya Bersih

\section{Pendahuluan}

Kerusakan yang terjadi di permukaan bumi ini merupakan akibat dari ulah tangan manusia dalam berinteraksi terhadap lingkungan hidupnya. Islam sesungguhnya agama yang sangat 324 Volume 29 Nomor 2 Juli-Desember 2018 
sempurna (kaffah), paling lengkap, dan mencakup segala urusan lahir dan batin, dunia dan akhirat, termasuk di dalamnya budaya hidup bersih dan suci (at-thaharah wa at-tanzih), baik rohani dan jasmani, walaupun keyakinan seperti ini agak berbau reifikasi, dan itu sah-sah saja, baik secara normatif-teoretik maupun secara empiris-historis. ${ }^{1}$

Secara eksplisit al-Qur'an telah menyatakan bahwa segala jenis keruskakan yang terjadi di permukaan bumi ini merupakan akibat dari ulah tangan manusia dalam berinteraksi terhadap lingkungan hidupnya. Al-Qur'an surat al-Rum ayat 41 Allah berfirman:

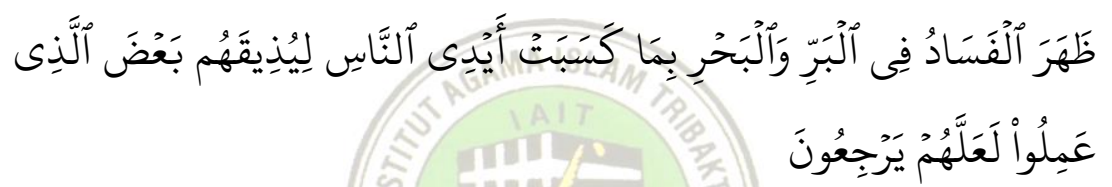

Terjemahnya: "Telah nampak kerusakan di darat dan di laut disebabkan karena perbuatan tangan-tangan (jahil) manusia, supaya Allah merasakan kepada mereka sebahagian dari (akibat) perbuatan mereka, agar mereka kembali (ke jalan yang benar)" (QS. al-Rum: 41). ${ }^{2}$

Ayat di atas sesungguhnya harus menjadi bahan introspeksi manusia sebagai makhluk yang diberikan mandat oleh Allah SWT untuk mengelola lingkungan hidup yang baik dan benar, bagaimana tata kelola lingkungan hudup yang baik dan yang seharusnya dilakukan agar tidak terjadi kerusakan alam semesta ini. Allah SWT. dengan tegas sudah melarang manusia melakukan kerusakan dalam bentuk apapun di muka bumi ini.

1 Masdar F. Mas'udi, Majalah An-Nadha'ir, Edisi 011/Tahun III/VII/1997 (Surabaya: POSSNU-Jatim, 1997), h. 46.

2 Departemen Agama RI, Al-Quran dan Terjemahnya, Proyek Pengadaan Kitab Suci al-Quran (Jakarta: Yayasan Penyelenggara Penterjemahan al-Qur'an, 1984-1985), h. 647.

Volume 29 Nomor 2 Juli-Desember 2018 


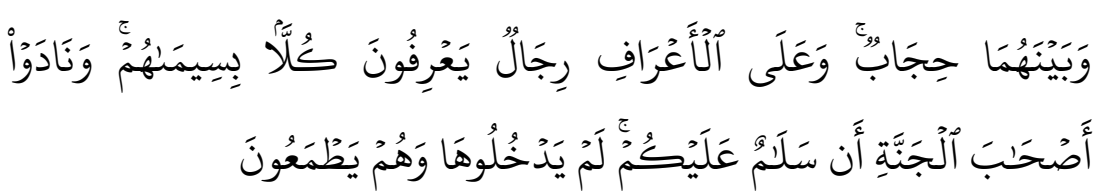

Terjemahnya: "Dan janganlah kamu membuat kerusakan di muka bumi, sesudah (Allah) memperbaikinya dan berdoalah kepada-Nya dengan rasa takut (tidak akan diterima) dan harapan (akan dikabulkan). Sesungguhnya rahmat Allah amat dekat kepada orang-orang yang berbuat baik" (QS. al-A'raf: 56$){ }^{3}$

Fatwa Majelis Ulama Indonesia (MUI) Nomor 20 Tahun 2011 tentang Pertambangan Ramah Lingkungan sebaga dasar hukum, Fatwa Majelis Ulama Indonesia (MUI) Propinsi Jawa Timur Nomor SKF Kep-15/SKF/MUI/JTM/2008 tentang Pencemaran Sungai di Surabaya, dan Undang-undang RI. Nomor 23 tahun 1997 tentang Pengelolaan Lingkungan Hidup sebagai hukum formal. ${ }^{4}$

Thahir bin Asyur dalam tafsir at-Tahrir wa Tanwir mengatakan bahwa yang dimaksud "melakukan kerusakan pada satu bagian dari lingkungan hidup searti (semakna) dengan merusak lingkungan hidup secara keseluruhan".

Dalam konteks ini, perumusan fiqh lingkungn hidup menjadi sangat penting dalam rangka memberikan pencerahan dan paradigma (landasan berpikir) bahwa fiqh tidak hanya berkutat pada masalah ubudiyah, muamalah dan ritual saja, tetapi bahasan fiqh meliputi tata aturan dan tata nilai yang sesuai dengan prinsip-prinsip agama terhadap berbagai realita sosial kehidupan yang sedang berkembang untuk maju ke depan. ${ }^{6}$

3 Departemen Agama RI, Al-Quran dan Terjemahnya, h. 230.

4 Undang-undang RI. Nomor 23 tahun 1997 tentang Pengelolaan Lingkungan Hidup (Jakarta: Menteri Sekretaris Negara RI. 1997), h. 87.

5 Muhammad Thahrir bin Asyur, at Tahrir wa at-Tanwir (Tunisia: As-Sadad at-Tunisiyah Lin-Nasyr, 1984), h. 174.

6 Sukarni, Fiqh Lingkungan Hidup (Banjarmasin: Antasari Press, 2011), h. 45. 
Dalam perspektif ajaran Islam, ada beberapa nilai religiusitas yang mendukung upaya pelestarian alam dan lingkungan hidup. Pertama, segitiga konsep God, Human Being \& Nature. Manusia harus menyembah Allah, bersikap egaliter (al-musawah/equality) terhadap sesama manusia walau berbeda latar belakang profesi, serta bersikap friendly terhadap alam. Alam dapat dieksplorasi (exploration) untuk kepentingan dan penopang kehidupan manusia, sepanjang tidak menjurus pada eksploitasi (exploitation) secara berlebihan. Sebagai contoh, proyek penambangan emas oleh PT. Freeport di Papua maupun timah di Bangka Belitung dan lain-lain, pada hakikatnya sudah mengarah pada eksploitasi, melebihi batas kewajaran naturaleksploratif. Akhirnya, kedua proyek penambangan tersebut berdampak negatif-destruktif pada alam sekitar termasuk penduduknya.

Kedua, dalam Islam dikenal konsep ketundukan alam (taskhir), di mana alam sengaja diciptakan sebagai "hamba" manusia demi kemakmuran bumi. Plus-minus ketundukan alam ini sangat tergantung pada kecerdasan nurani manusia dalam mengelola alam. Ketiga, konsep keseimbangan/tawazun (equilibrium) di mana Allah SWT. sudah sejak awal menciptakan alam secara berimbang demi kepentingan manusia, hewan dan benda alam lainnya. Belakangan, manusia sendiri yang destruktif terhadap alam. Keempat, asas pemanfaatan (intifa') bahan baku alam yang diolah menjadi bahan jadi.

Kelima, konsep pembelajaran (i'tibar) dari alam sebagai makhluk tuhan agar manusia dapat lebih tawadhu' kepada sang pencipta melalui pengamatan/tafakkur alam. Hal ini sering dilakukan Nabi Muhammad SAW di saat beliau pembimbing ke Jabal Nur (Gua Hira'). Dari alam kita bisa belajar kearifan (wisdom/hikmah) tentang keteraturan, keheningan dan kejernihan hati dan pikiran yang kelak berdampak pada perilaku yang positif-konstruktif bagi sesama. 
Keenam, konsep ishlah, yaitu prinsip menjaga kelestarian bumi/alam serta menjauhkan diri dari sikap destruktif (fasaad). Ketujuh, konsep pemakmuran bumi (i'timar) demi pewarisan alam bagi generasi masa depan yang lebih baik. Tugas manusia sebagai khalifah adalah memakmurkan bumi melalui kerja-kerja kemanusiaan (amal saleh). Kedelapan, alam tidak dijadikan secara sia-sia (wa ma khalaqta hadza bathila).

Kesembilan, objektivitas alam (sunnatullah), di mana hukum alam bersifat objektif bagi yang ada di alam ini. Sebagai contoh, apabila sebuah gedung diberi penangkal petir (arde) sementara masjid tidak diberi, maka apabila ada petir, kemungkinan bangunan gedung lebih selamat ketimbang masjid. Hal sama berlaku bagi manusia, siapa pun yang melestarikan alam, tanpa memandang suku, etnis dan agama, maka alam akan lebih bersahabat padanya ketimbang yang tidak bersahabat dengan alam, sekalipun dia seorang Muslim. Kesepuluh, umumnya musibah yang ada disebabkan ulah manusia sendiri (dharal fasadu fil barri wal bahri bima kasabat aidinnas).

Dalam warisan hadits-hadits Nabi Muhammad SAW banyak ditemukan bagaimana kearifan Nabi dalam menjaga lingkungan, di antaranya Nabi memerintahkan umatnya untuk menyingkirkan duri dari jalanan, larangan buang air kecil di lobang semut, larangan merusak/membakar pohon atau tanaman milik musuh walau dalam keadaan perang, larangan buang hajat di kolam-kolam air yang tergenang, perintah Nabi Muhammad SAW untuk konservasi satwa seperti burung, semut, kodok, dan lain-lain.

Berikut contoh-contoh kerusakan yang terjadi di alam yang sebagian besar karena ulah manusia, di antaranya: banjir, fenomena hutan beton/bangunan di kota-kota besar yang mereduksi ruang terbuka hijau, penyempitan lebar dan pendangkalan kedalaman sungai, abrasi laut/sungai, pembuangan (penumpukan) sampah secara sembarangan, polusi 
lingkungan dan udara yang menimbulkan efek rumah kaca, abrasi pantai, longsor akibat penggundulan hutan, pembalakan liar, penggunaan pupuk non-organik (zat kimia) bagi tanaman dan mencemarkan tanah yang berdampak pada tereduksinya ketersediaan tanah dan air jernih (di AS pernah ada sebuah kota kecil yang terlihat asri, namun setelah puluhan tahun terpaksa ditinggal oleh penduduknya mengingat air tanahnya sudah tercermar zat kimia), serta bentuk perusakan alam/lingkungan lainnya. Allah berfirman :

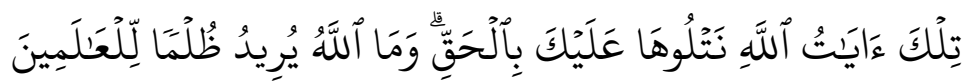

Terjemahnya: "Itulah ayat-ayat Allah, Kami bacakan ayat-ayat itu kepadamu dengan benar dan tiadalah Allah berkehendak untuk menganiaya hamba-hamba-Nya" (QS. Ali Imran: 108). ${ }^{7}$

Allah SWT menciptakan alam ini bukan tanpa tujuan. Alam ini merupakan sarana bagi manusia untuk melaksanakan tugas pokok mereka yang merupakan tujuan diciptakan jin dan manusia. Alam adalah tempat beribadah hanya kepada Allah semata. Allah berfirman:

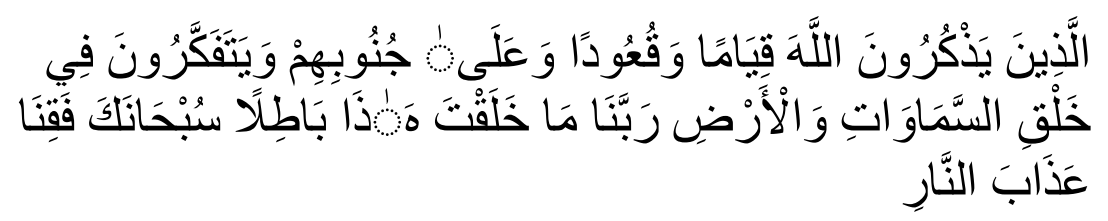

Terjemahnya: "(Yaitu) Orang-orang yang mengingat Allah sambil berdiri atau duduk atau dalam keadaan berbaring dan mereka memikirkan tentang penciptaan langit dan bumi (seraya berkata), "Ya Rabb kami, tiadalah Engkau menciptakan ini dengan sia-sia, maha suci Engkau, maka peliharalah kami dari siksa neraka" (Ali Imran: 191). ${ }^{8}$

7 Departemen Agama RI., Al-Quran dan Terjemahnya, h. 93.

8 Departemen Agama RI, Al-Quran dan Terjemahnya, h. 647.

Volume 29 Nomor 2 Juli-Desember 2018 
Syariat Islam sangat memperhatikan kelestarian alam, meskipun dalam tananam pohon, al-Qurthubi berkata dalam tafsirnya, "bercocok tanam termasuk fardhu kifayah. Imam (penguasa) berkewajiban mendesak rakyatnya untuk bercocok tanam dan yang semakna (sejenis) dengan itu, seperti menanam pohon". 9

Bahkan untuk memotivasi umat beliau agar gemar menanam pohon dan sejenisnya, beliau bersabda :

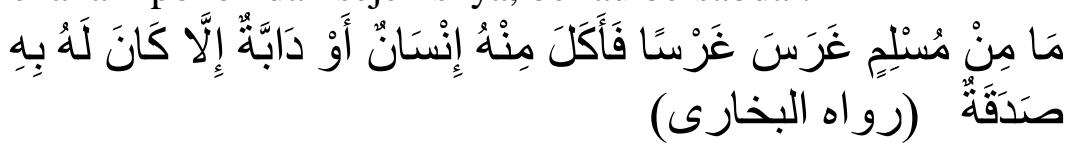

Artinya: "Umat muslim (di mana saja) yang menanam sebuah pohon lalu ada orang atau hewan yang memakan dari pohon tersebut, niscaya akan dituliskan baginya sebagai pahala sedekah" (HR. Bukhari). ${ }^{10}$

\section{Pembahasan}

\section{Pengertian Fiqh Lingkungan Hidup}

Menurut istilah, lingkungan hidup diartikan sebagai totalitas (keseluruhan) dari benda, daya, dan kehidupan, termasuk manusia dan perilakunya yang mempengaruhi kelangsungan hidup dan kesejahteraan manusia serta jasad-jasad hidup (organisme) lainnya. ${ }^{11}$

Pengertian fiqh lingkungan hidup dalam bahasa Arab dipopulerkan dengan istilah "fiqh al-bi'ah" yang terdiri dari 2 (dua) kata (kalimat majemuk): "mudhaf dan mudhaf ilaihi" yaitu kata "fiqh dan al-bi'ah". Secara bahasa, kata fiqh berasal dari

9 Tafsir al-Qurthubi, Juz, III, h. 306.

10 Muhammad bin Ismail bin Ibrahim al-Mughirah al-Bukhari, Shahih Al-Bukhari, Juz V (Kairo: Dar al-Sya'ab, 1987), h. 6012.

11 Abdusshomad Buchori, Konsepsi Islam tentang Lingkungan Hidup (Surabaya: MUI Jatim \& Asshomadiyah Centre, 2011), h. 6. 
kata: faqiha, yafqahu, fiqhan, yang berarti al-ilmu bis-syari'i (pengetahuan terhadap sesuatu) al-fahmu (pengetahuan). ${ }^{12}$

Sedangkan secara istilah, fiqh adalah ilmu pengetahuan tentang hukum-hukum syara' yang bersifat praktis yang diambil dari dalil-dalil tafshili (terperinci). ${ }^{13}$

Dalam al-Qur'an tidak kurang dari 19 (sembelan belas) ayat yang berkaitan dengan kata fiqh, semuanya dalam bentuk kata kerja, sebagaimana surat at-Taubah ayat 122:

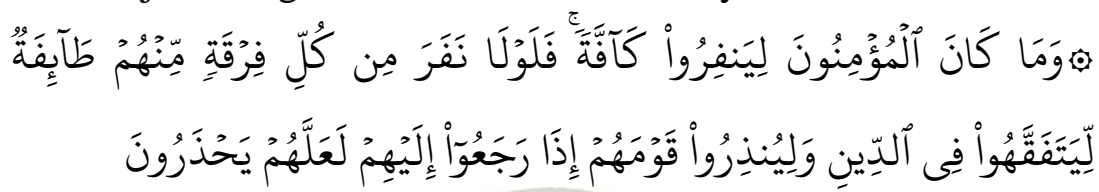

Terjemahnya: "Tidak sepatutnya bagi mukminin itu pergi semuanya (ke medan perang), mengapa tidak pergi dari tiap-tiap golongan di antara mereka beberapa orang untuk memperdalam pengetahuan mereka tentang agama dan untuk memberi peringatan kepada kaumnya apabila mereka telah kembali kepadanya, supaya mereka itu dapat menjaga dirinya" (QS. al-Taubah, 122). ${ }^{14}$

Sedangkan kata al-bi'ah dapat diartikan dengan lingkungan hidup, yaitu kesatuan ruang dengan semua benda, daya, keadaan dan makhluk hidup, termasuk manusia dan perilakunya yang mempengaruhi alam itu sendiri, perikehidupan dan kesejahteraan manusia serta makhluk hidup lainnya. ${ }^{15}$

Dengan demikian dapat dipahami bahwa fiqh lingkungan hidup adalah ketentuan Islam yang bersumber dari dalil-dalil yang terperinci tentang perilaku manusia terhadap lingkungan

12 Muhammad bin Ya'qub al-Fayrus Abadi, Al-Qamus Al-Muhith (Beirut: Muassasah Ar-Risalah, 2005) cet. VIII, h. 1250.

13 Jamaluddin Abdurrahim bin Hasan al-Asnawi, Nihayah as-Sul Fi Syarhi Minhaji Wushul ila Ilmu al-Ushul (Bairut: Dar Ilmu Hazm, 1999), cet 1, Juz 1, h. 16.

14 Departemen Agama RI, Al-Quran dan Terjemahnya, h. 90.

${ }^{15}$ Abdusshomad Buchori, Konsepsi Islam, h. 89.

Volume 29 Nomor 2 Juli-Desember 2018 
hidupnya dalam rangka mewujudkan kemaslahatan dan menjauhkan dari kerusakan.

\section{Pengertian Thaharah}

Thaharah (bersuci) menurut bahasa berarti bersih dan membersihkan diri dari kotoran yang bersifat hissiy (inderawi) seperti najis dan kotoran yang ma'nawi seperti cacat fisik maupun nonfisik (aib). Sedangkan menurut syara', thaharah adalah sesuatu yang dihukumi wajib untuk melaksanakan shalat seperti wudhu, mandi, tayammum dan menghilangkan najis lainnya. Beberapa macam thaharah, yaitu wudhu untuk menghilangkan hadats kecil, mandi untuk menghilangkan hadats besar serta tayamum untuk menggantikan wudlu dalam keadaan tertentu. Thaharah pada dasarnya adalah sebuah ibadah yang mencakup seluruh ibadah lainnya. Tanpa adanya thaharah mustahil akan terwujud ibadah yang sah karena ibadah yang dilakukan seorang hamba harus dalam keadaan yang bersih dan suci (thaharah wa nadhafah) untuk mencapai kesempurnaan ibadah.

Thaharah menurut bahasa berarti bersuci. Menurut syara' atau istilah adalah membersihkan diri, pakaian, tempat, dan benda-benda lain dari najis dan hadats menurut cara-cara yang ditentukan oleh syariat Islam. Thaharah (bersuci) adalah syarat wajib yang harus dipenuhi dan dilakukan dalam beberapa macam ibadah sebagaimana al-Quran surat al-Maidah ayat 6 sebagai berikut:

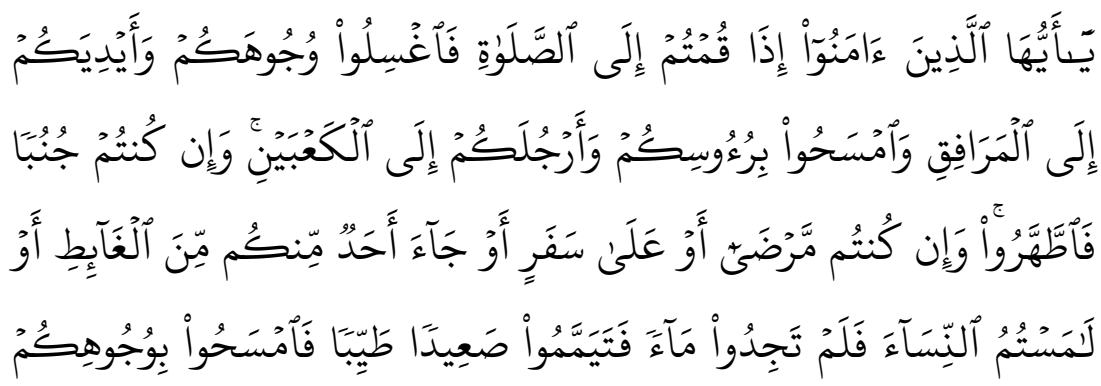




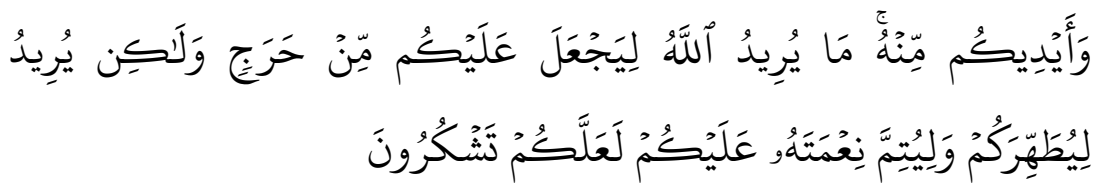

Terjemahnya: "Wahai orang-orang yang beriman, apabila kamu hendak mengerjakan shalat, maka basuhlah mukamu dan tanganmu sampai dengan siku, dan sapulah kepalamu dan (basuh) kakimu sampai dengan kedua mata kaki, dan jika kamu junub, maka mandilah, dan jika kamu sakit (sakit yang tidak boleh kena air) atau dalam perjalanan atau kembali dari tempat buang air (kakus) atau menyentuh perempuan, lalu kamu tidak memperoleh air, maka bertayammumlah dengan tanah yang baik (bersih); sapulah mukamu dan tanganmu dengan tanah itu (tayamum). Allah tidak hendak menyulitkan kamu, tetapi Dia hendak membersihkan kamu dan menyempurnakan nikmat-Nya bagimu, supaya kamu bersyukur" (QS. al-Maidah: 6)

Menurut Daud al-Dlahiri mengatakan bahwa air terkena najis, baik air mengalir maupun diam (tenang), apabila air tersebut tidak mengalir dan najisnya dapat dilihat dengan mata, selain bangkai yang tidak memiliki darah yang mengalir dan terjadi perubahan salah satu sifat air tersebut, maka air dihukumi najis. ${ }^{16}$ Sesuai dengan sabda Nabi Muhammad SAW:

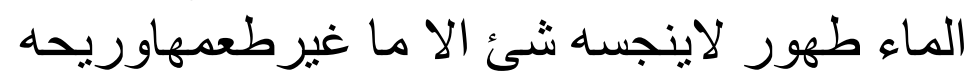

Artinya: Air hukumnya suci, sesuatu apapun tidak dapat menajiskan air tersebut kecuali rasa dan baunya berubah. ${ }^{17}$

Thaharah (bersuci) menurut pembagianya dapat dibedakan menjadi 2 (dua) bagian, yaitu:

1. Bersuci Lahiriah

16 Muhadzab, Juz I, Maktabah Samilah, h. 18.

17 Sunan Daruqutni, Juz I, Darul Ma'rifah, Cet. I, 1966, h. 28.

Volume 29 Nomor 2 Juli-Desember 2018 
Thaharah (bersuci) yang bersifat lahiriah adalah membersihkan diri, tempat tinggal, lingkungan dari segala bentuk kotoran, hadats dan najis. Membersihkan diri dari najis adalah membersihkan badan, pakaian, dan tempat yang didiami dari kotoran sampai hilang rasa, bau dan warnanya. (QS. al-Muddassir ayat 4).

\section{Bersuci Batiniah}

Thaharah (bersuci) batiniah adalah membersihkan jiwa dari kotoran batin berupa dosa dan perbuatan maksiat seperti: iri, dengki, takabur dan sombong. Cara membersihkannya dengan taubatan nashuha (taubat yang sungguh-sungguh), yaitu memohon ampun kepada Allah SWT dan berjanji tidak akan mengulang kembali perbuatan tersebut.

Ada beberapa pernyataan yang sudah sangat populer di tengah masyarakat, namun sebenarnya masih perlu mendapatkan penelitian dan pencermatan yang mendalam, yaitu pernyataan: آَنَََّافَةُ مِنَ الْإِيْمَانِ (kebersihan bagian dari keimanan). Ungkapan kata di atas sangat populer, sehingga pernyataan ini dapat diketemukan dalam berbagai media penyiaran: baliho, baik cetak maupun elektronik, pamflet, poster, stiker dan bahkan iklan layanan masyarakat di media cetak, maupun elektronik. Banyak juga juru dakwah, pengkhutbah (pemberi kultum), sambutan-sambutan dari para pejabat yang mengutip pernyataan ini dan menjadikannya sebagai dalil akli.

Hasil penelusuran ilmu hadits terhadap pernyataan : مآنَََََّفَةُ مِنَ الْإِيْمَانِ (kebersihan bagian dari keimanan) ditemukan bahwa redaksi yang berbunyi : آلنَّظَافَةُ مِنَ الِْإِيْمَانِ (kebersihan bagian dari keimanan) bukan merupakan hadits Nabi. Dalam kalimat lain Nabi Muhammad SAW tidak pernah bersabda dengan redaksi: آلََََََّفَةُ مِنَ الْْإِيَْانِ (kebersihan bagian dari keimanan). Tetapi Nabi Muhammad SAW pernah bersabda: الَطُُْهُرْ شَطْرُ الْإِيْمَانِ (kesucian itu separuh keimanan). Redaksi terakhir ini merupakan 
penggalan (potongan) dari hadits shahih yang lengkapnya adalah sebagai berikut :

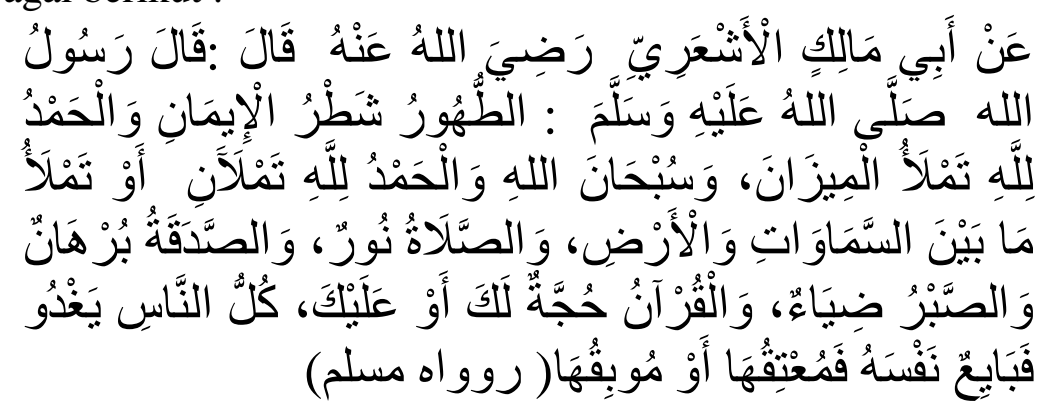

Artinya: Dari Abu Malik al-Asy'ari ia berkata, Rasulullah SAW bersabda: "Kesucian itu separuh keimanan, ucapan alhamdulillah memenuhi timbangan, ucapan subhanallah walhamdulillah keduanya memenuhi memenuhi antara langit dan bumi, shalat itu cahaya, sedekah itu bukti, kesabaran itu sorot sinar, al-Quran itu hujjah yang menguntungkanmu atau merugikanmu dan semua orang memasuki pagi harinya lalu menjual dirinya, lalu ia membebaskannya atau membinasakannya" (H.R. Muslim). ${ }^{18}$

\section{Perbedaan antara Thaharah \& Nadhafah,}

Perbedaan antara redaksi thaharah dan nadhafah, di antaranya:

1. Dalam hadits shahih, kata yang digunakan adalah kata thaharah, sedangkan kata yang populer adalah nadhafah. Thaharah berarti suci, (kesucian). Sedangkan nadhafah berarti bersih, atau kebersihan.

2. Dalam hadits shahih, kata yang digunakan adalah syathr yang berarti separuh, (setengah belahan), sedangkan dalam redaksi yang populer, kata yang digunakan adalah min yang berarti sebagian, dapat sebagian kecil, meskipun dapat juga berarti sebagian besar.

18 Muslim bin al-Hajjaj bin Muslim bin Warad, Shahih Muslim (Riyad: Dar al-Alam al-Kutub, 1986), h. 114. 
3. Dalam terminologi Islam, ada perbedaan antara bersih dan suci, sebab tidak semua yang bersih adalah suci, meskipun terkadang dalam skala kecil, yang suci pun terkadang dianggap tidak bersih.

4. Secara makna kata syathr menunjuk kepada sesuatu yang bulat, lalu dibelah persis pada posisi di tengah-tengahnya. Hasil dari pembelahan ini masing-masingnya disebut syathr. Dengan demikian dalam redaksi "kesucian itu separuh keimanan" maknanya, iman itu dianggap sebagai benda yang nilainya $100 \%$, lalu dibelah menjadi dua bagian 50\%-nya adalah hal-hal yang berkenaan dengan kesucian, sedangkan yang $50 \%$ sisanya, insya allah merupakan hal-hal yang bersifat menghiasi atau (mengisi). ${ }^{19}$

5. Dengan demikian keimanan itu 50\%-nya mensucikan atau mengosongkan. Istilahnya adalah takhliyah (تخلية) dan 50 $\%$ lagi adalah menghiasi atau mengisi, istilahnya tahliyah (تحلية)..$^{20}$

Sedangkan kata "min" yang berarti sebagian, tidak secara pasti menunjuk kepada nilai 50\% dari sesuatu, sebab, nol koma satu $(0,1)$ pun dapat disebut sebagian, meskipun $99 \%$ pun juga bisa disebut sebagian. Nadhafah bersifat lahiriyah, sedangkan thaharah lahir dan bathin.

Kata nadhafah lebih mengarah kepada hal-hal yang bersifat lahiriyah, tampak dan kasat mata, sedangkan kata suci, pemaknaannya dapat sangat luas dan mendalam, mencakup aspek lahir yang tampak dan kasat mata, dan juga mencakup

19 Abdurrahman bin Nashir As-Sa'di, Bahjat Qulub al-Abrar wa Qurratu Uyunil Akhyar fi Syarhi Jawami'il Akhbar (Mesir: Maktabah Syamilah, 1421), h. 220.

20 Ibn Utsaimin, Syarhul Arba'in an-Nawawiyah (Bairut: Dar alAlam al-Kutub, tth), h. 220. 
aspek batin yang tidak tampak dan tidak kasat mata. ${ }^{21}$ Cakupan makna thaharah dalam terminologi Islam mencakup hal-hal sebagai berikut:

1. Thaharah dari segala bentuk kemusyrikan, sebab dalam pandangan Islam, patung-patung, berhala dan segala bentuk penyembahan kepada selain Allah SWT itu terhitung sebagai rijsun (رجس) di mana orang beriman diwajibkan menjauhinya (QS. al-Maidah: 90), (QS. alA'raf: 70 - 71), sama rijs-nya dengan bangkai, darah dan daging babi (QS. al-An'am: 145).

2. Thaharah dari segala bentuk kemunafikan, karenanya, pada akhirnya, Rasulullah SAW diperintahkan oleh Allah SWT untuk berpaling dari orang-orang munafik, alasan Allah SWT adalah karena mereka itu rijsun (QS. alTaubah: 95).

3. Thaharah dari segala sifat dan akhlak tercela, seperti: hasad (iri), hiqd (dengki) dan semacamnya. Sebab sifatفي (فifat tercela ini menjadikan hati manusia berpenyakitan serta perlu mendapatkan tazkiyah (proses penyucian).

4. Thaharah dari segala bentuk dosa dan maksiat, karenanya kaum Nabi Luth bermaksud mengusir Nabi Luth, alasan mereka, karena Nabi Luth tidak mau berbuat dosa bersama mereka. Istilahnya : innahum unasun yatathahharun (QS. al-A'raf: 82) (QS. al-Naml: 56).

5. Thaharah dari hal-hal yang membuat hati "ngeres: bahasa. Jawa" (seksualitas) dikarenakan urusan syahwat, khususnya syahwat kemaluan. Sebagaimana diceritakan tentang orang-orang yang di dalam hatinya ada penyakit, baik dikarenakan oleh syubhat maupun oleh syahwat,

21 al-Askari, Mu'jamul Furuq al-Lughawiyyah (Mesir: Maktabah alQur'niyah, 1423), h. 339. 
maka Allah semakin tambahkan kepada mereka rijsan ila rijsihim (QS. al-Taubah: 125).

6. Thaharah dari segala hadats, baik hadats kecil maupun hadast besar. Dalam pandangan Islam, orang yang junub /mandi setelah hubungan seksualitas dengan istrisuami/keluar air mani, meskipun kelihatan bersih, yang bersangkutan tidak suci) karenanya, kalau hendak shalat wajib mandi terlebih dahulu. Begitu juga dengan orang yang kentut, dalam pandangan Islam, bukanlah orang yang suci, meskipun dalam keadaan sangat bersih, karenanya, kalau hendak shalat, harus berwudhu lebih dahulu.

7. Thaharah dari segala bentuk najis, baik yang tidak tampak (najis hukmi) maupun yang tampak (najis 'aini).

8. Thaharah dari segala bentuk kotoran dan debu, meskipun kotoran dan debu itu tidak najis, karenanya Islam mengajarkan agar paling tidak atau minimal seorang muslim mencuci kepalanya satu kali dalam setiap mau melaksanan shalat Jum'at, agar kepalanya itu bersih dan suci.

9. Thaharah dalam Islam bahkan mencakup juga sunanul fithrah (sunnah-sunnah kesucian fithrah), yang di antaranya memotong kuku, mencabuti bulu ketiak dan sejenisya. $^{22}$

Dengan demikian terminologi thaharah dalam Islam pengertianya sangat luas, namun dalam keluasan pengertian itu, makna dan cakupannya, semua bersifat takhliyah (pembersihan, penyucian dan pengosongan), karenanya disebut sebagai syathrul iman (separuh keimanan), di mana yang separuhnya lagi bersifat tahliyah (menghiasi atau mengisi), sebagaimana telah dijelaskan di atas.

Karena keluasan cakupan, makna dan pengertian thaharah inilah, redaksi yang tersebut dalam hadits shahih, yaitu الطهور

22 Abdusshomad Buchori, Konsepsi Islam, h. 17. 
شطر الإيمان (kesucian adalah separuh keimanan), maknanya jauh lebih mendalam dibandingkan dengan redaksi yang sudah sangat populis : النظافة من الإيمان (kebersihan sebagian dari pada iman), sebab terminologi nadhafah makna, cakupan dan pengertiannya tidaklah sedalam makna, cakupan dan pengertian thaharah. ${ }^{23}$

\section{Urgensi Lingkungan Hidup dalam Islam}

a. Melestarikan lingkungan hidup merupakan manifestasi keimanan seseorang yang konsisten terhadap kebersihan lingkungan, baik thaharah maupun nadhafah, sebagaimana dijelaskan dalam al-Qur' an surat al-A'raf ayat 85:
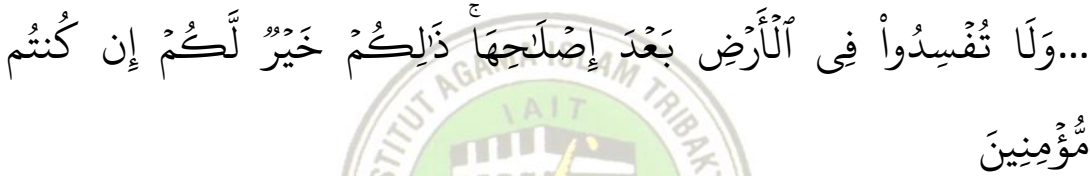

Terjemahnya: ... dan janganlah kamu membuat kerusakan di muka bumi sesudah Tuhan memperbaikinya. Yang demikian itu lebih baik bagimu apabila betul-betul kamu orang-orang yang beriman (QS. al-A'raf, 85). ${ }^{24}$

b. Merusak lingkungan adalah sifat orang munafik dan pelaku kejahatan, sebagaimana dijelaskan dalam al-Qur'an surat alBaqarah ayat 205:

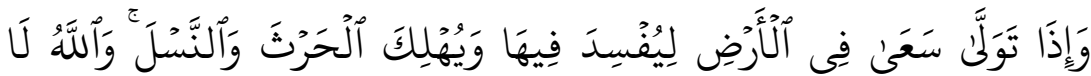
يُحِبُّ ألْفَسَادَ

Terjemahnya: dan apabila ia berpaling (dari kamu), ia berjalan di bumi untuk mengadakan kerusakan padanya, dan

23 Abu Daud Sulaiman al-Asy'ats as-Sijistani, Sunan Abi Daud (Bairut: Dar al-Kitab al-Arabi, t.th.), h. 19.

${ }^{24}$ Departemen Agama RI, Al-Quran dan Terjemahnya, h. 235.

Volume 29 Nomor 2 Juli-Desember 2018 
merusak tanam-tanaman dan binatang ternak, dan Allah tidak menyukai kebinasaan (QS. al-Baqarah, 205). ${ }^{25}$

c. Kerusakan yang terjadi di muka bumi, karena ulah tangan manusia, sebagaimana firman Allah dalam surat ar-Rum, 41:

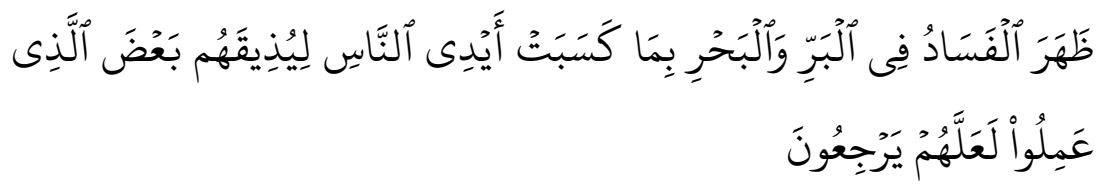

Terjemahnya: Telah nampak kerusakan di darat dan di laut disebabkan karena perbuatan tangan manusia, supaya Allah merasakan kepada mereka sebahagian dari (akibat) perbuatan mereka, agar mereka kembali (ke jalan yang benar) (QS. al-Rum, 41).

Dalam rangka usaha pemeliharan lingkungan hidup, termasuk memungkinkan pengembangan dan peningkatan kualitasnya, maka ajaran Islam menekankan dan memberikan motivasi yang kuat bagi terjalinnya hubungan yang baik (serasi) antara manusia dengan dirinya, dan sesamanya serta dengan alam lingkungannya.

d. Pelestarian Lingkungan Hidup Perspektif al-Hadits. Sesuai dengan ayat-ayat al-Quran di atas, Rasulullah telah menambahkan nilai-nilai implementasi pemeliharaan dan pelestarian lingkungan hidup sebagaimana hadits di bawah ini:

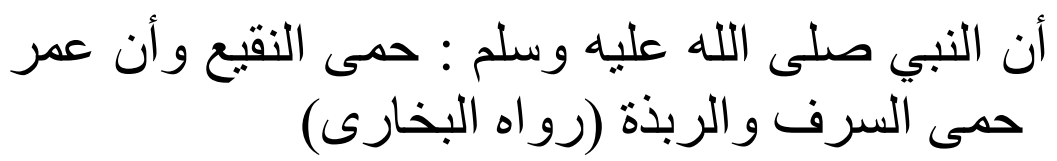

Artinya: "Sesungguhnya Rasulullah SAW telah menetapkan Naqa' sebagai daerah konservasi, begitu pula

${ }^{25}$ Departemen Agama RI., Al-Quran dan Terjemahnya, h. 647. 
Umar menetapkan Saraf Rabudzah sebagai daerah konservasi" (HR. Bukhari). ${ }^{26}$

Demikian juga Rasulullah SAW telah menganjurkan menanam pohon dan tanaman lainnya, sebagaimana Rasulullah bersabda:

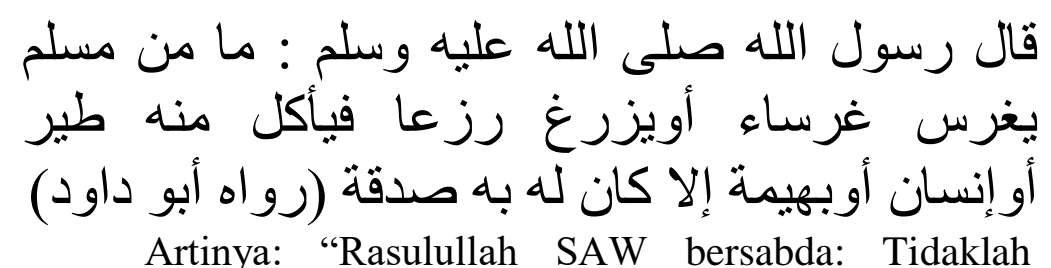

seorang muslim menanam sebuah pohon atau sebuah taanaman kemudian dimakan oleh burung, manusia dan binatang, melainkan ia akan mendapat pahala sedekah" (HR. Abu Dawud). ${ }^{27}$

Dalam hadits lain larangan melakukan pencemaran lingkungan hidup, sebagai berikut :

قال رسول الله صلى الله عليه وسلم : اتقوا الملاعن الثلاث البراز فى الموارد وقار عة الطريق

Artinya: Rasulullah SAW bersabda: Takutlah (kalian) terhadap tiga perkara yang (dapat) menimbulkan laknat; 1) buang besar di saluran air (sumber mata air), 2) di tengah jalan raya (jalan umum), 3) di tempat teduh (di bawah pohon tempat berkumpul orang)". ${ }^{28}$

\section{Pelestarian Lingkungan Perspektif Fiqh}

Fiqh sebagai disiplin ilmu yang mengatur hubungan antara manusia dengan Allah, manusia dengan diri sendiri, hubungan manusia dengan manusia, dan hubungan manusia dengan lingkungan hidup sekitarnya, maka fiqh tidak dapat diragukan

26 Muhammad bin Ismail bin Ibrahim al-Mughirah al-Bukhari, Shahih Al-Bukhari, Juz V, (Kairo: Dar al-Sya'ab, 1987), h. 6.

27 Al-Bukhari, Shahih Bukhari, h. 135.

${ }^{28}$ As-Sijistani, Sunan Abi Daud, h. 11. 
lagi bahwa fiqh memilik peran krusial dalam merumuskan tata kelola lingkungan hidup yang sesuai dengan Islam.

Yusuf al-Qardhawi mengatakan bahwa fiqh sangat concern terhadap isu-isu lingkungan hidup. Hal ini dapat dibuktikan dengan pembahasan-pembahasan yang terdapat dalam literatur fiqh klasik, seperti pembahasan thaharah (kebersihan), ikya al-mawat (membuka lahan tidur), al-musaqat wa al-muzara'ah (pemanfatan lahan milik orang lain), muamalah al-ba'i (transaksi jual-beli), dan kepemilikan air, api, garam dan hak-hak binatang pemeliharaan serta pembahasan lainnya tentang lingkungan hidup. ${ }^{29}$

Pemeliharaan lingkungan hidup merupakan upaya untuk menciptakan kemaslahatan dan pencegahan kemudharatan. Hal sesuai dengan konsep maqasidul syariah (tujuan syariah agama) yang dirumuskan dalam kulliat al-hams: 1) hifdzu al-nafs (melindungi jiwa) 2) hifdzu al-aql (melindungi akal pikiran), 3) hifdzu al-mal, (melindungi harta benda/properti), 4) hifdzu alnasb (melindungi keturunan/nasab), 5) hifdzu al-din (melindungi agama) yang dianutnya. ${ }^{30}$

Menjaga kelestarian lingkungan hidup merupakan tuntutan untuk melindungi kelima tujuan syariah tersebut. Oleh karena itu seluruh perilaku yang mengarah kepada kerusakan lingkungan hidup, maka searti (semakna) dengan perbuatan jiwa, akal, harta, keturunan, dan agama yang dianutnya (diikuti). Demikian juga sistem penerapan hukuman (sanksi) orang yang melanggar kerusakan lingkungan hidup adalah berupa denda dan hukuman kurungan (at-ta'zir) yang ditentukan oleh pemerintah (waliyyul amr).

\section{Penutup}

29 Yusuf al-Qardhawi, Ri'ayatu al-Bi'ah fi as-Syari'ah al-Islamiyah (Kairo: Dar al-Syuruq, 2001), h. 39.

30 al-Qardhawi, Ri'ayatu al-Bi'ah, h. 44. 
Dari uraian di atas dapat penulis simpulkan bahwa figh albi'ah ramah lingkungan, konsep thaharah dan nadhafah dalam membangun budaya bersih hakikatnya berupa konsep aturan yang meliputi :

1. Konsep fiqh al-bi ah ramah lingkungan adalah konsep aturan yang dirumuskan oleh Islam dalam rangka mengatur kemaslahatan dan kemanfaatan bagi manusia yang berorientasi pada kelestarian lingkungan hidup sesuai dengan al-Qur'an dan al-Hadits.

2. Kaitannya dengan manusia sebagai khalifah di bumi harus berdasarkan asas kemanfaatan yang benar untuk menghindari kerusakan (janganlah kamu membuat kerusakan di muka bumi ini, sesudah (Allah) memperbaikinya dan berdo'alah kepada-Nya).

3. Orientasi tata kelola lingkungan hidup perlu ditanamkan sejak dini kepada setiap pribadi umat Islam dan menjadi tanggung jawab bersama dan pemerintah yang memiliki otoritas dan pemegang regulasi dalam menjaga dan melestarikan lingkungan hidup dan mengantisipasi dampak kerusakannya.

4. Dalam hadits yang shahih, kata yang digunakan adalah kata thaharah (suci), sedangkan kata yang populer adalah nadhafah (bersih, atau kebersihan).

5. Pernyataan yang sudah sangat populer di tengah masyarakat, namun sebenarnya masih perlu mendapatkan penelitian dan pencermatan yang mendalam, yaitu pernyataan : (kebersihan bagian dari keimanan). Wallahu al-A'lam. 


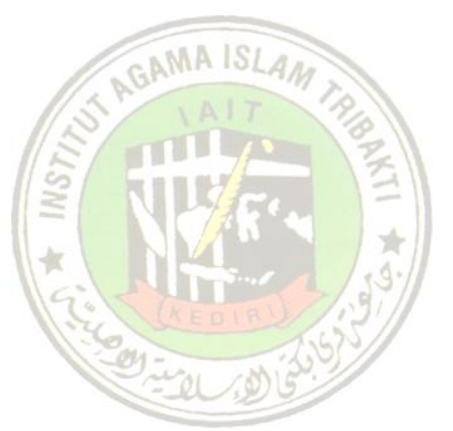




\section{DAFTAR PUSTAKA}

Abadi, Muhammad bin Ya'qub al-Fayrus. Al-Qamus Al-Muhith, cet. VIII. Beirut: Muassasah Ar-Risalah, 2005.

Al-Askari. Mu'jamul Furuq al-Lughawiyyah. Mesir: Maktabah al-Qur'niyah, $1423 \mathrm{H}$.

Al-Asnawi, Jamaluddin Abdurrahim bin Hasan. Nihayah as-Sul Fi Syarhi Minhaji Wushul ila Ilmu al-Ushul, Juz 1, cet 1. Bairut: Dar Ilmu Hazm, 1999.

Al-Bukhari, Muhammad bin Ismail bin Ibrahim Al-Mughirah. Shahih Bukhari, Juz V. Kairo: Dar Al-Sya'ab, 1987.

Al-Qardhawi, Yusuf. Ri'ayatu al-Bi'ah fi as-Syari'ah alIslamiyah. Kairo: Dar al-Syuruq, 2001.

As-Sa'adi, Abdurrahman bin Nashir. Bahjat Qulub al-Abrar wa Qurratu Uyunil Akhyar fi Syarhi Jawami'il Akhbar, (Mesir: Maktabah Syamilah, 1421/H).

As-Sijistani, Abu Daud Sulaiman al-Asy'ats. Sunan Abi Daud, Bairut: Dar al-Kitab al-Arabi, t.th.

Asyur, Muhammad Thahrir bin. at Tahrir wa at-Tanwir. Tunisia: As-Sadad at-Tunisiyah Lin-Nasyr, 1984Buchori, Abdusshomad. Konsepsi Islam tentang Lingkungan Hidup \& Undang-Undang Republik Indonesia Nomor 32 Tahun 2009 Tentang Perlindungan dan Pengelolaan Lingkungan Hidup. Surabaya: MUI Jatim dan Asshomadiyah Centre, 2011.

Departemen Agama RI. Al-Qur'an dan Terjemahnya. Jakarta: Yayasan Penyelenggara Penterjemahan al-Qur'an, 1984-1985.

Mas'udi, Masdar F. Majalah An-Nadha'ir, Edisi 011/Tahun III/VII/1997, Surabaya: POSSNU-Jatim, 1997.

Muslim bin al-Hajjaj bin Muslim bin Warad. Shahih Muslim. Riyad: Dar al-Alam al-Kutub, 1986. 
SJ, Ahmad Syafi'i. Fiqh Lingkungan Revitalisasi Ushul Fiqh untuk Konservasi dan Restorisasi Kosmos. Surakarta: Annual Conference of Islamic Studies, 2009.

Sukarni. Fiqh Lingkungan Hidup. Banjarmasin: Antasari Press, 2011.

Undang-undang RI. Nomor 23, tentang Pengelolaan Lingkungan Hidup, (Jakarta: Menteri Negara Sekretasi Negara RI., 1997.

Utsaimin, Ibn. Syarhul Arba'in an-Nawawiyah. Bairut: Dar alAlam al-Kutub, t.th. 